\begin{tabular}{|c|c|c|c|}
\hline \multirow{2}{*}{$\begin{array}{r}\text { Case Reports in } \\
\text { Gastroenterology }\end{array}$} & \multicolumn{2}{|c|}{ Case Rep Gastroenterol 2017;11:59-63 } & \multirow[b]{2}{*}{ Oparger } \\
\hline & $\begin{array}{l}\text { DOI: } 10.1159 / 000455186 \\
\text { Published online: February 28, } 2017\end{array}$ & $\begin{array}{l}\text { (c) } 2017 \text { The Author(s)Published by S. } \\
\text { Karger AG, Basel } \\
\text { www.karger.com/crg }\end{array}$ & \\
\hline & $\begin{array}{l}\text { This article is licensed under the } \\
\text { International License (CC BY-NC) } \\
\text { Usage and distribution for commerci }\end{array}$ & $\begin{array}{l}\text { nons Attribution-NonCommercial } \\
\text { ger.com/Services/OpenAccessLicense) } \\
\text { uires written permission. }\end{array}$ & \\
\hline
\end{tabular}

\title{
Giant Fecalith Causing Near Intestinal Obstruction and Rectal Ischemia
}

\author{
Sofia Nigar Tagore Sunkara $^{\mathrm{a}} \quad$ Andrea Culliford $^{\mathrm{b}} \quad$ Vinaya Gaduputi $^{\mathrm{b}}$ \\ ${ }^{a}$ Department of Internal Medicine, The Brooklyn Hospital Center, Brooklyn, NY, USA; \\ ${ }^{b}$ Department of Internal Medicine, SBH Health System, Bronx, NY, USA
}

\section{Keywords}

Fecalith · Fecal impaction - Constipation - Complications of fecalith · Intestinal obstruction .

Rectal ischemia $\cdot$ Rectal ulcer

\section{Abstract}

Fecal impaction if left untreated can lead to the hardening of stools and the formation of fecalith. Fecaliths rarely cause serious complications and are usually managed conservatively. We present this rare case of a giant fecalith causing near obstruction in an institutionalized paraplegic patient at high risk for chronic constipation and fecal impaction. This case was also unusual for causing ischemic pressure necrosis in the rectum, thereby highlighting the possible serious complications of fecalith.

(C) 2017 The Author(s)

Published by S. Karger AG, Basel

\section{Background}

Fecal impaction occurs when a large amount of fecal matter gets compacted and cannot be evacuated spontaneously [1]. It can occur in any part of the intestine. Fecal impaction is significantly common in chronic, severe constipation and in other at-risk patients with anatomical or functional anorectal abnormalities. Fecal impaction in its extreme form can lead to the hardening of stools and the formation of fecaliths. Fecaliths rarely causes serious complications and are generally managed conservatively. Herein, we present a rare case of a 


\section{Case Reports in Gastroenterology}

Case Rep Gastroenterol 2017;11:59-63 DOI: 10.1159/000455186

(c) 2017 The Author(s). Published by S. Karger AG, Basel www.karger.com/crg

Nigar et al.: Giant Fecalith Causing Near Intestinal Obstruction and Rectal Ischemia

giant fecalith causing near obstruction in an institutionalized patient at high risk for fecal impaction due to paraplegia.

\section{Case Report}

A 73-year-old paraplegic woman with an indwelling Foley catheter for recurrent urinary tract infections was admitted with complaints of pressure-like, nonradiating, bilateral lowerquadrant abdominal pain (intensity 9/10) associated with 2 episodes of diarrhea mixed with streaks of bright red blood which was preceded by chronic constipation. The patient also had a history of pulmonary embolism and was taking Coumadin. On admission, the patient was dizzy and found to be hypotensive with blood pressure of 88/59. She responded to intravenous hydration. Laboratory values were consistent for microcytic anemia with hemoglobin of $9.1 \mathrm{~g} / \mathrm{dL}$ and mean corpuscular volume of 79 . A CT scan of the abdomen with oral and intravenous contrast showed a circumferential mass in the rectum (Fig. 1) and findings consistent with constipation. Colonoscopy revealed a large near-obstructing fecalith in the rectum (Fig. 2). There was severe ulceration with oozing of blood on contact and heaped edges in the distal rectum. All endoscopic attempts at removal of the fecalith were unsuccessful due to its size and its extremely hard stone-like consistency. A small piece of the fecalith was broken down and sent to histopathology. Biopsy of the rectal ulcer showed ischemic necrosis (Fig. 3). The patient subsequently underwent manual disimpaction under general anesthesia in the operating room. The patient was put on round-the-clock stool softeners and subjected to periodic manual disimpaction to prevent a recurrence.

\section{Discussion}

Fecal impactions are commonly encountered in clinical practice and are a frequent cause for emergency department visits [2]. Chronic constipation, anatomic anorectal abnormalities (such as strictures, stenosis, Chagas disease, and Hirschsprung disease), and functional anorectal abnormalities (such as pelvic floor dysfunction, abnormal rectal sensation, and increased rectal compliance) increase the risk of fecal impaction [3]. However, the elderly and those with neuropsychiatric diseases are at the highest risk of developing fecal impaction. Rarely, if untreated, fecal impaction can lead to the development of fecaliths, which is hardening of stools. Fecaliths most commonly occur in the rectum and sigmoid colon. Patients with fecaliths usually present with overflow diarrhea, constipation, and abdominal pain [4]. They rarely cause severe complications. Rectal ischemia as seen in this patient is rare due to its dual blood supply. However, in this case, the patient developed rectal ischemia secondary to pressure from the giant rectal fecalith. An increase in intra-abdominal pressure caused by the fecalith decreases capillary perfusion and can lead to ischemic necrosis [5]. Prolonged ischemia such as this might cause ulceration, gastrointestinal bleeding, and even perforation. Fecaliths can also cause intussusception, intestinal obstruction, and extraluminal pressure effects leading to urinary retention and hydronephrosis [5-9]. The hardness of stools depends on the degree of calcification and the presence of solid material [10]. Fecaliths are usually amenable to conservative management with digital disimpaction, laxatives, or enemas. If conservative management is unsuccessful, they can be removed during colonoscopy. Fecaliths very rarely require surgical removal. 


\section{Statement of Ethics}

This case report was exempted from our Institutional Review Board as per its policy. Informed consent for participation was obtained from the patient.

\section{Disclosure Statement}

None of the authors have any financial conflicts of interest to declare.

\section{References}

1 Zhao W, Ke M: Report of an unusual case with severe fecal impaction responding to medication therapy. J Neurogastroenterol Motil 2010;16:199-202.

-2 Corban C, Sommers T, Sengupta N, Jones M, Cheng V, Friedlander E, Bollom A, Lembo A: Fecal impaction in the emergency department: an analysis of frequency and associated charges in 2011. J Clin Gastroenterol 2016;50:572-577.

- 3 Obokhare I: Fecal impaction: a cause for concern? Clin Colon Rectal Surg 2012;25:53-58.

-4 Yoo HY, Park HW, Chang SH, Bae SH: Ileal fecaloma presenting with small bowel obstruction. Pediatr Gastroenterol Hepatol Nutr 2015;18:193-196.

5 Serrano Falcón B, Barceló López M, Mateos Muñoz B, Álvarez Sánchez A, Rey E: Fecal impaction: a systematic review of its medical complications. BMC Geriatr 2016;16:4.

-6 Mahajna A, Krausz MM: Ileocolic intussusception in an adult patient due to a cecal fecalith. Isr Med Assoc J 2009;11:58-59.

7 Watters AN, Tomashefski JF Jr, Malangoni MA: Colonic obstruction resulting from fecalith in patients with scleroderma. Am Surg 2011;77:364-366.

8 Knobel B, Rosman P, Gewurtz G: Bilateral hydronephrosis due to fecaloma in an elderly woman. J Clin Gastroenterol 2000;30:311-313.

-9 Tan CK, Lai CC, Kan WC, Chan KS: Hydronephrosis caused by fecal impaction. Kidney Int 2008;73:10991100.

10 Attila T, Kabaoglu B, Koymen T, Unal Kabaoglu Z: Fecalith causing mechanical bowel obstruction managed with intracorporeal lithotripsy. ACG Case Rep J 2016;3:156-157.

Data relating to this case report is available from the corresponding author upon request 


\begin{tabular}{|c|c|c|}
\hline \multirow{2}{*}{$\begin{array}{l}\text { Case Reports in } \\
\text { Gastroenterology }\end{array}$} & \multicolumn{2}{|c|}{ Case Rep Gastroenterol 2017;11:59-63 } \\
\hline & DOI: $10.1159 / 000455186$ & $\begin{array}{l}\text { O } 2017 \text { The Author(s). Published by S. Karger AG, Basel } \\
\text { www.karger.com/crg }\end{array}$ \\
\hline
\end{tabular}

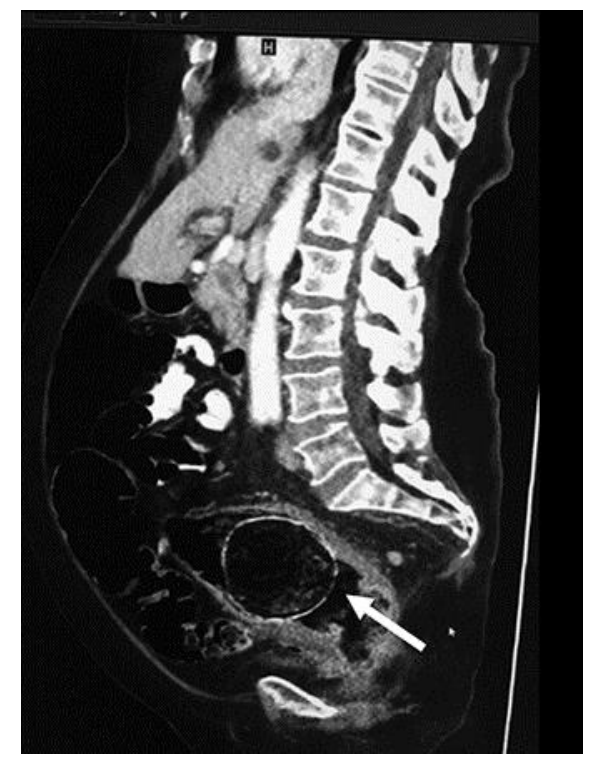

Fig. 1. CT Abdomen showing a rectal endoluminal fecalith mimicking a mass lesion (white arrow).
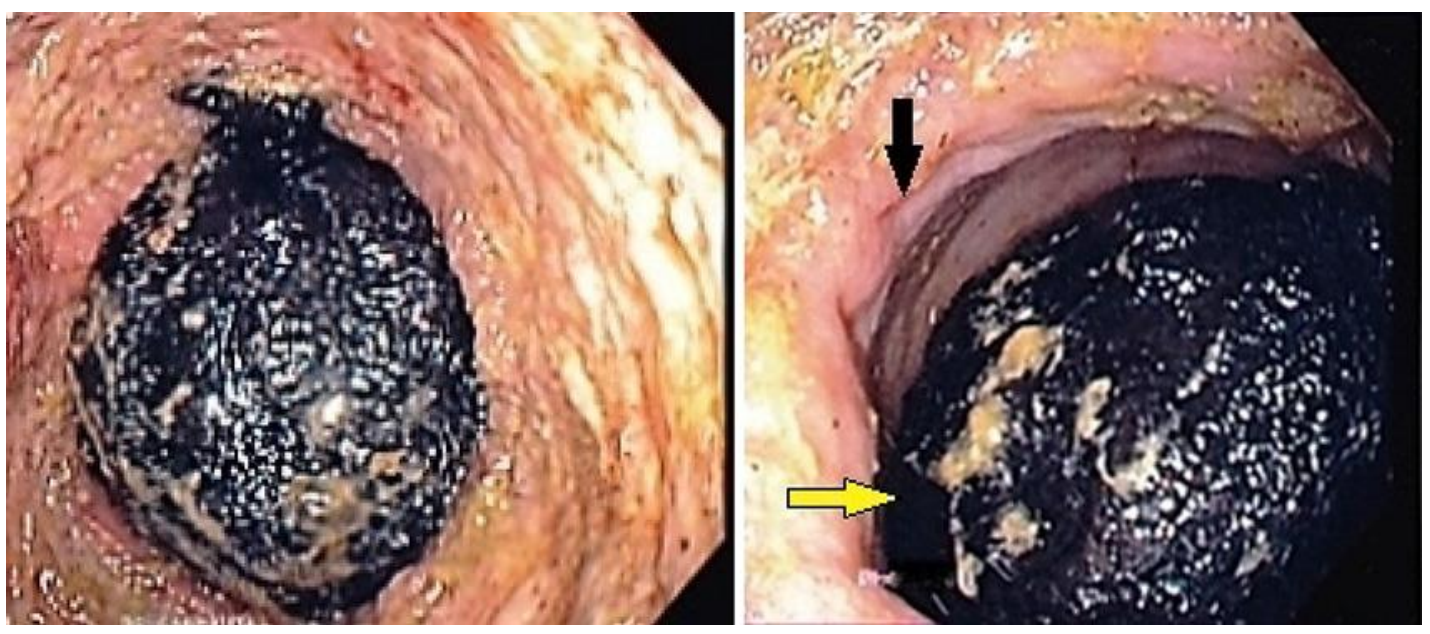

Fig. 2. Giant near-obstructing fecalith (yellow arrow) in the rectum with surrounding mucosal ulcerations (black arrow). 


\begin{tabular}{|c|c|c|}
\hline \multirow{2}{*}{$\begin{array}{l}\text { Case Reports in } \\
\text { Gastroenterology }\end{array}$} & \multicolumn{2}{|c|}{ Case Rep Gastroenterol 2017;11:59-63 } \\
\hline & DOI: $10.1159 / 000455186$ & $\begin{array}{l}\text { O } 2017 \text { The Author(s). Published by S. Karger AG, Basel } \\
\text { www.karger.com/crg }\end{array}$ \\
\hline
\end{tabular}

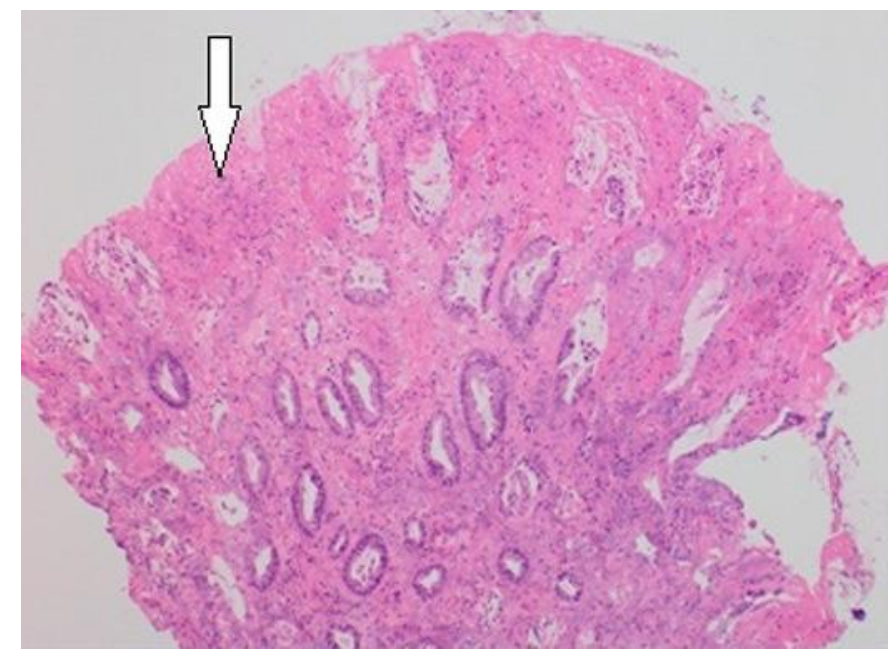

Fig. 3. Rectal biopsy specimen showing evidence of ischemic necrosis (white arrow) on H\&E stain. $\times 100$. 